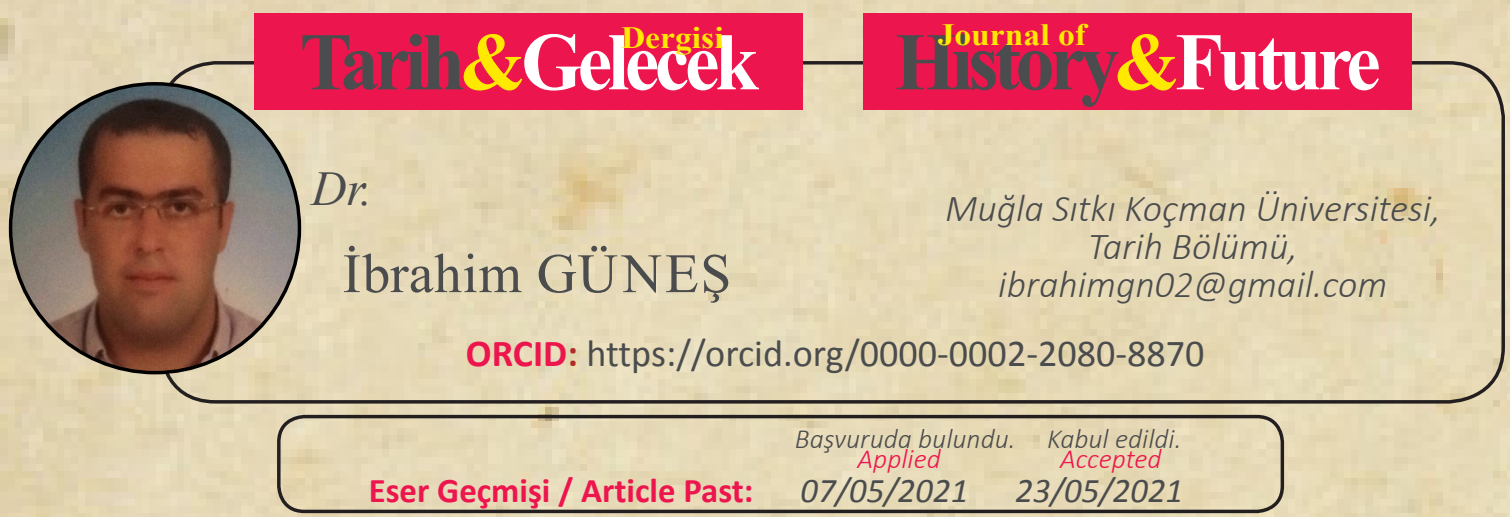

Araştırma Makalesi

DOI: http://dx.doi.org/10.21551/jhf.934216

Research Paper

Indexed by

ERIHPIUAT

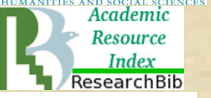

Q] $\mathbf{I} \mathbf{S A}$

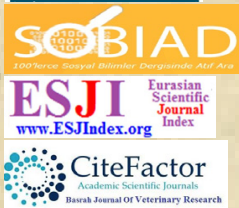

ideal

Orjinal Makale / Orginal Paper

\title{
İslam Tarihi Kaynaklarına Göre İlhanlıların Suriye Seferi (1259-1260)
}

\author{
According to Islamic Sources Ilkhanids Syria Campaign
}

(1259-1260)

Öz

Hülegü, Alamut ve Bağdad'ı zapt ettikten sonra Suriye'yi ele geçirmek üzere 1259 yılında büyük bir askerî sefer başlatmıştır. Moğollar birçok yoldan ilerlerken, ilk olarak el-Cezire bölgesine girip Amid, Meyyafarikin ve Mardin şehirlerini ele geçirmişlerdir. İlhanlıların bir diğer ordu ise Ruha ve Harran'1 zapt etmiştir. Eyyûbî hükümdarı el-Melikü’n-Nâsır'ın Moğollar önünde başarısız olması üzerine birçok Müslüman emir veya asker Mısır'a iltica etmek zorunda kalmışlardır. Moğolların buradaki en büyük başarısı ise Halep ve Dımaşk’1 ele geçirmeleri olmuştur. Nitekim Ketboğa Noyan komutasındaki Moğol ordusunun yaptığı birçok saldırılardan sonra Halep Kalesi Hülegü’ye teslim olmak zorunda kalmış, Dımaşk halkı da İlhanlı hükümdarına elçi yollayarak teslim olmak istediklerini bildirmişlerdir. Ardından Hülegü, yaklaşık 10.000 askeri komutanlarından Ketboğa Noyan’a bırakıp Karakurum’a dönmüştür. Ketboğa Noyan ise Mısır'a haber yollayıp teslim olmalarını istemiştir. Bu sırada tahtı yeni ele geçirmiş olan Memlûk Sultanı Kutuz, Baybars ve Kalavun gibi emirlerin 1srarı üzerine Moğollar üzerine yürümeye karar vermiştir. Neticede büyük bir seferberlik ilan edilmiş ve Moğolları 1260 yılında Ayn-1 Calut'ta savaşa mecbur bırakmışlardır. İki taraf arasında yaşanan bu şiddetli savaştan sonra, Moğollar tarihte ilk defa yenilgi almış ve başta Ketboğa Noyan olmak üzere ordunun önemli bir kısmı yok edilmiştir. $\mathrm{Bu}$ savaşın ardından bölgedeki Moğol ilerlemesi durduğu gibi Moğollar tümü ile Fırat'ın doğusuna atılmışlardır. Çalışmamızda ise bu sürecin İslam tarihi kaynaklarına göre anlatımı yapılmıştır.

Anahtar Kelimeler: Arap Kaynakları, İlhanlılar, Eyyûbîler, Hülegü, Suriye.

ATIF: GÜNEŞ İbrahim, "İslam Tarihi Kaynaklarına Göre IIlhanlıların Suriye Seferi (1259-1260)”, Tarih ve Gelecek Dergisi, 7/2

: (Haziran 2021), s. (791-804)

CITE: GÜNEŞ İbrahim, "According to Islamic Sources Ilkhanids Syria Campaign (1259-1260)", Journal of History and Future

7/2 (June 2021), pp. (791-804) 


\begin{abstract}
After the capture of Alamut and Baghdad, Hulegu launched a large military expedition in 1259 to seize Syria. As the Mongols proceeded in many ways, they first entered the al-Jazeera region and captured the cities of Amid, Meyyafarikin and Mardin. Another army of Ilkhanid captured Ruha and Harran. When the Ayyubid ruler al-Meliku-Nasir was unsuccessful in front of the Mongols, many Muslim orders or soldiers had to take refuge in Egypt. The biggest success of the Mongols here was the takeover of Aleppo and Damascus. As a matter of fact, after many attacks carried out by the Mongolian army under the command of Ketboğa Noyan, Aleppo Castle had to surrender to Hulegu, and the people of Damascus reported that they wanted to surrender by sending news to the Ilkhanid ruler. Afterwards, Hulegu left Ketbokha Noyan, one of the approximately 10,000 military commanders, and returned to Karakurum. Ketbokha Noyan sent an envoy to Egypt and asked them to surrender. Meanwhile, the Mamluk Sultans Kutuz, who had recently taken the throne, decided to walk on the Mongols at the insistence of orders such as Baibars and Kalawun. As a result, a great mobilization was declared and the Mongols forced the war in Ayn-i Calut in 1260. After this violent war between the two sides, the Mongols were defeated for the first time in history and a significant part of the army, especially Ketbokha Noyan, was destroyed. After this war, Mongol progress in the region stopped and Mongols were thrown to the east of Euphrates. In our study, this process was explained according to Islamic historical sources.
\end{abstract}

Key Words:Arab Sources, Ilkhanids, Eyyubids, Hulegu, Syria.

\title{
Giriş
}

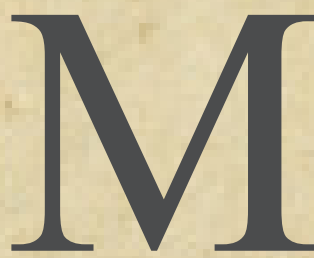

oğolların İslam dünyası üzerine istila teşebbüsleri, Cengiz Han devrinden başladığı, halefleri Ögeday Han ve Göyük Han devrinde de hız kaybetmeden devam ettiği görülmektedir. Özellikle Mönge Han devrinden (1243-1259) itibaren Büyük Moğol İmparatorluğu'nun Cengiz Han'ın soyundan gelenler tarafından yönetildiği çeşitli şubelere ayrılması sonucu Moğolların işgal ettikleri yerlerde Moğol şehzadelerinin yönetime geçtiği merkezi hükümetler kurulmaya başlanmıştır. Göyük Han'ın 1250 yılında ölmesi üzerine Mönge Han'ın başa geçmesiyle başlayan süreç, nihayetinde batıda Bağdad, İran, el-Cezire ${ }^{1}$ ve Anadolu üzerinde hâkimiyet tesis edecek İlhanlı Devleti'nin kurulmasıyla neticelenmiştir ${ }^{2}$. Nitekim Reşîdüddîn,

1 Mezopotamya'nın kuzey bölümünü ifade etmektedir. Ortaçağ kaynakları bölgeyi IX. yüzyıldan itibaren Diyâr-1 Rebîa, Diyâr-1 Mudar ve Diyâr-1 Bekr olmak üzere üç kısma ayırdıkları görülmektedir. Bkz. Makdisî, Makdîsî, Ahsenü't-Takasim fi Marifetü'l-Ekalim, (Neşr. M.J. de Goeje), Leyden 1877, s. 137; İstahrî, Kitabu'l-Mesalik ve'l-Memalik, (Neşr. M.J. de Goeje), Leyden 1927, s.71-78; İbn Havkal, Sûretu'lArz, (Neşr.M.J. de Goeje), Leyden 1874, s.207-240; el-İdrisî, Nüzhetü'l-Müştâk, II, Beyrut 1989, s.655; Ebu'l-Fida, Takvimü'l-Büldân, (M.Reinaud), Paris 1840, s.273; Yakut el-Hamavî, Mu'cemü'l-Büldân, II, Beyrut 1977, s.561-562; İbn Şeddâd, el-Alâku'l-Hatira fi Zikri Ümerai Şam ve'l-Cezire, (Neşr. Y. Abbare), III/I, Dımaşk 1978, s.4-5; Zekeriyâ Kâzvinî, Asaru'l-Bilad ve Ahbaru'l-İbad, Beyrut 1960, s.351

2 Devletin tarihi seyri hakkında bkz. Spuler, Iran Moğolları, (Çev.Cemal Köprülü), Ankara 1987, ilgili yerler; a.mlf, "İlhanlılar", $\dot{I} A$, V/2, s.967-972; a.mlf., "İlkhâns", $E I^{2}$, s.1121-1123; Y. Vladimirtsov, Moğolların İçtimai Teşkilâtı, (Çev. Abdülkadir İnan), Ankara 1944, s. 62-70. 
Mönge Han'ın tahta geçer geçmez küçük kardeşi Kubilay’1 70.000 asker ile Çin'e3 , Cûzcânî de diğer kardeşi Hülegü'yü ${ }^{4}$ Güneybatı Asya topraklarını fethetmek için gönderdiğini kaydeder. ${ }^{5}$

Hülegü, bizzat Mönge Han'ın tasdik ettiği ve 1252 yılındaki kurultaydan aldığı ferman gereğince batı toprakları üzerine güçlü bir ordu ile harekete geçti. ${ }^{6}$ Mâverâünnehr ve Horasan bölgelerinde bir süre oyalandıktan sonra ${ }^{7}$ nihayetinde 1255 yılından itibaren harekât hız kazanmaya başladı. İlhanlı hükümdarı, 24 Temmuz 1256 tarihinde İsmaillilere ait Alamut Kalesi'ni ${ }^{8}$ muhasara altına aldı ve kale 18 Eylül 1256 tarihinde teslim olmak zorunda kaldı. Mukavemet eden birçok müdafi katledildiği gibi İsmaililerin şeyhi Hürşah da büyük Moğol hakanı Mönge Han'ın huzuruna çıkarıldıktan sonra boynu vuruldu. ${ }^{9}$ Geri kalanlar ise sayım yapılacak bahanesi ile toplanıp idam edildiler. Reşîü̈ddîn, sadece küçük bir kısmın dağlara sığınarak kurtulabildiğini kaydeder. ${ }^{10}$ Alamut'un zaptından sonra İlhanlılar yönlerini Suriye ve Mısır'a yöneltmişlerdir. Bu teşebbüs

3 Mustafa Kafalı, Altın Orda Hanlığının Kuruluş ve Yükseliş Devirleri, İstanbul 1976, s.52.

4 İlhanlı Devleti’nin ilk hükümdarıdır. Babası Çingiz Han'ın en küçük oğlu Tuluy Han, annesi Ong Han’ın yeğeni Sorgaktani Hatun'dur. Doğum tarihi tam olarak belli olmadığı gibi gençlik yıllarına ait bilgimiz çok azdır. 663/1265 yılında ölmüştür. Hayatı ve icraatları hakkında bkz. Bertold Spuler, Iran Moğolları (Çev. Cemal Köprülü), Ankara 1987, s. 59-77; Rene Grousset, Bozkır Imparatorluğu, İstanbul 1980, s.331-349; Abdü's-Selam Abdü'l-Aziz Fehmî, Tarih-i Devleti Moğoliye fi Iran, Kahire 1981, s. 108-150; Abbas İkbâl, Tarih-i Moğul, I, Tahran 1926, s. 164-199; Abdulkadir Yuval1, Ilhanlılar Tarihi I Kuruluş Devri, Kayseri 1994, s. 45-114; aynı mlf, "Hülâgû", DİA, XVIII, s.474-475; Özdemir, Moğol İstilass Cengiz ve Hülagü Dönemleri, İstanbul 2011, s.183-311; Faruk Sümer, “Anadolu'da Moğollar”,SAD, I, 1979, s. 24-36; V.V. Barthold, "Hülagu”, $\dot{I} A$, V/1, s. 581-582.

5 Kalkaşandî, Hülegü’nün İran toprağını Batu Han'dan aldığını kaydeder ki (Subh el-'Aşâ fî Sinâ 'at el-İnşâ, IV, Kahire 1913-1920, , s.309), muasır kaynakların hiç birinde İran’ın Batu’nun kontrolüne girdiğine dair bir kayıt bulamadık. Bu nedenle söz konusu bilgi yanlış olmalıdır.

6 Makrizî, Kitabu's-Sulûk li Marifet'ud-Duvel Mulûk, (Neşr. Mustafa Ziyade), I, Kahire 1956, s.418-419; Yuvali, age.,s.52.

7 Zehebî, Târîhu'l-İslâm ve Vefeyâtü'l-Meşâhîr ve'l-A'lâm, (Tah: Ömer Abdüsselam Tedmuri), XLVIII, Beyrut 1997, s.8.

8 Alamut veya Alamut Kalesi, İran'da Elburz dağlan üzerinde olup, Kazvin'in kuzeydoğusunda müstahkem bir kaledir. Deylem sınırındaki Rûdhâne-i Alamut vadisi ile Tâlekân nehrinden 2, Kazvin'den ise 6-8 fersah mesafede 2000 m. yükseklikteki yüksek ve ele geçirilmesi zor bir kaya üzerinde kurulmuştur. Bkz. Zekeriyâ Kâzvinî, Asaru'l-Bilad ve Ahbaru'l-İbad, Beyrut 1960, s.301-302; Hamdullah Müstevfî, Nüzhetü'l-Kulûb, Neşr: Le Strange, Leiden 1908, s. 61; Zeki Velidi Togan. "Alamut”, IA, I, s.289; L Lockhart. "Alamut", $E I^{2}$, I, 352.

9 Baybars el-Mansûrî, Zübdet el-Fikre fi Tarih el-Hicre (Tah. D. S. Richards), Beyrut 1998, s.8; İbnü'lCezerî, Havâdisü'z-zaman ve enbâuh ve vefeyâtü'l-ekâbir ve'l-a'yân emlin ebnâih/Muhtar Tarih-i İbnü'l-Cezerî (Tah. Hizır Abbas Muhammed Halife el-Mendşedavî ), Beyrut 1988, s.240; İbn Dokmak, s.224; Yunînî, Zeyl Miratu'z-Zaman, I, Haydarabad 1955, s.11; Ebu'l-Farac, Ebû'l-Farac Tarihi, (Çev. Ömer Rıza Doğrul), II, Ankara 1999, s.561-562; Benâketî, Ravzatü'l-Ulî'l-Elbâb fi Tevarîhü'l-Ekabir ve'l-Ensab(Tarih-i Benâketî), (Neşr: Ca'fer Şi'ar), Tahran 1348/1969, s.415-416; Stèphannos Orbèlian, Histoire de la Siounia,( Neşr. M.Brosset), Saint-Pètersburg 1864, s.229; Mhithar, Vakayiname, (Neşr. M.Brosset), Sen-Petersbourg 1869, s.108; Jean d'Outremeus, Chronique, (Neşr. Ad. Borgnet), V, Bruxelles 1867, s.319-320; Zehebî, Tarihü'l-İslam, XLVIII, s. 25; a.mlf, Düvelü'l-İslam, (Neşr. Hasan İsmail Merket-Mahmud el-Ernaut), II, Beyrut 1999, s. 159; Yafi'î, Miratü'l-Cinan ve İbretü'l Yakzan Ma'rife ma Yu'teber min Havadis ez-Zaman,(Neşr. Halil el-Mansur), IV,Beyrut 1997, s.135; Kalkaşandî, IV, s.309-310; İbn Tagrîbirdî, en-Nucûm ez-Zâhire fi Mulûk Misr ve el-Kahire, (Tah.İ.Ali Tarhan-M. Mustafa Ziyade), VII, Kahire 1963, s.37; İbn Sibât, Sidk el-Ahbar: Tarih-i İbn Esbat, (Tah. Abdülselam Tedmurî),I, Trablus 1993, s.367.

10 Reşîduddîn/Neş'et, I, s.245. 
devrin İslam dünyasını dehşete düşürmüş ve olaya bizzat şahitlik eden birçok müellifin bu felaketi eserlerine kaydetmesine sebep olmuştur. Burada da devrin İslam kaynaklarına göre İlhanlıların Suriye seferi hakkında müstakil bir değerlendirmede bulunulacaktır.

\section{Hülegü'nün Suriye Üzerine Yürümesi}

Moğollar için Bağdad'ın zaptı ile Suriye bölgesinin yolu açılmıştı. Bunun yanında Dımaşk hâkimi Sultan Melikü'n-Nâsır Selâhaddin, Musul hükümdarının Moğollara tabi olmaląrının iyi netice verdiğini görünce, oğlu el-Melikü' '-Azîz'i değerli hediyelerle Hülegü' ye göndermişti. İlhanlı hükümdarı, el-Melikü'l-Aziz'i kabul edip babasının neden gelmediğini sormuş, o da babasının muhtemel bir Haçlı istilasına karşı memleketinde kaldığını söylemiştir. Hülegü ise söz konusu cevabı makul bulacak ki el-Melikü'l-Azîz'i babasına geri göndermiştir. ${ }^{11}$

Bunun yanında Meyyâfârikîn hükümdarının Moğollara itaati reddetmesi, Hülegü’yü kalabalık bir ordu ile Amid üzerine yürümeye sevk etmesine sebep olmuştur (Zilhicce 657/Aralık 1259). Şehir önlerine geldiğinde Mardin hükümdarına haber gönderip itaat etmesini isterken, Mardin hükümdarı İl-Gazî12 kendi yerine oğlu Karaarslan'ı gönderince Hülegü buna çok sinirlenmiştir. İlhanlı hanı, babasının neden gelmediğini sorunca oğlu Mardin hâkiminin Sultan el-Melikü'nNâsır Selâhaddin'in tarafını tuttuğundan gelmediğini söylemiştir. Hülegü bu cevap karşısında iyice hiddetlenerek “Eğer Melikü'n-Nâsır Selâhaddin'in beni engelleyecek gücü olsaydl, buralara gelmeme izin vermezdi. Duyduğuma göre ailesini ve bazı emirlerini Mısır'a göndermiş” şeklinde sert bir cevap vermiştir. Bunun yanında Hülegü, Karaarslan'ın kendisine verdiği cevabı hiç beğenmemiş ve kendisine karşı bir ittifakın oluştuğundan şüphelenmiş olacak ki derhal Sultan Melikü'n-Nâsır Selâhaddin'e haber gönderip yanına gelmesini istemiştir. Melikü’n-Nâsır tekrar oğlu el-Melikü'l-Azîz'i gönderince İlhanlı hükümdarı bu duruma iyice sinirlenmiş ve " $O$ gelmezse biz onun memleketine varırız" diyerek el-Melikü'n-Nâsır'a tehditler savurmuştur. Hülegü, oğlu ile birlikte tehditlerle dolu bir mektubu Melikü'n-Nasır'a göndererek derhal kendisine itaat etmesini istemiştir. ${ }^{13}$

Vaziyetin vahametini anlayan el-Melikü’n-Nâsır, derhal Mısır'a haber göndererek Moğollara karşı yardım istediği görülmektedir. Bunun yanında bir taraftan Moğollara karşı müdafaa tedbirleri alırken diğer yandan da kendi ve büyük emirlerinin ailelerini Mısır'a göndermiştir. Suriye halkı Moğolların bölgeyi tehdit etmeleri üzerine telaşa düşerek memleketlerini terk edip Mısır'ın yolunu tutmuşlardı. İbnü'l-Kesir bu göç sırasında birçok insanın yolda öldüğünü, malları yanlarında olan birçok tüccarın da söz konusu mallarının yollarda yağmalandığını kaydederler. ${ }^{14}$ Suriye bölgesinde bunlar olurken Mısır'da da işler pek yolunda değildi. Nitekim Moğollar tüm askeri kudretleriyle el-Cezire ve Suriye üzerine çöktükleri bir sırada, tahta yeni geçmiş Eyyûbî Sultanı el-Melikü'lMansûr, birçok hükümdarlık vasfindan mahrum birisiydi. O güne kadar ki en büyük tehditle karşı karşıya olmalarına rağmen herhangi bir girişimde bulunmuyordu. İşte bu sırada saltanat naibi Kutuz

11 İbnü'l-Amîd, s.47; Baybars el-Mansûrî, Zübde, s.42-43; Ebu'l-Farac, II, s.572-573; İbn Dokmak, s.242; İbnü'l-Kesir, XIII, s.381; Makrizî, I, s.410-411; el-Aynî, I, s.179.

12 1239-1259 yılları arsında Artuklu hükümdarlığı yapmıştır. Bkz. K. Sussheim, "Kutb al-Din İl-Gazi II", IA, V/2, s. 966-967. Keza adına basılan sikkeler hakkında bkz. İsmail Galib,age, s. 69; Artuk, Artuk Oğullart Sikkeleri, s. 405.

13 İbn Şeddad, el-Alaku'l-Hatıra, III/II, s.489-490, 559; Ebu'l-Farac, II, s.573;Aknerli Grigor, s.29; Yunînî, I, s.91; Mirhond, V,s.259.

14 İbnü’l-Kesir, XIII, s.381. 
15, Melikü'n-Nâsır'dan da Moğolların Suriye bölgesini tehdit ettiğini yazan bir mektup ulaşınca, bu Sultan ile Moğollar gibi amansız bir düşmanla baş edilemeyeceğini dile getirerek derhal kudretli bir hükümdarın başa geçmesi için emirlerin nezdinde çalışmaya başlamıştır. Bu çabasının sonucunu da almıştır. Nitekim büyük emirler ittifakla Kutuz'un sultan olmasını istemişlerdir. Bu münasebetle Sultan el-Melikü'l-Mansûr 24 Zilkade 657/8 Kasım 1259 tarihinde annesi ile birlikte gözaltına alınıp Kahire kalesinin bir burcuna hapsedilmiştir. Kısa bir süre sonra da Kutuz müstakil sultan olarak kabul edilerek büyük emirlerin ortak kararı ile tek başına Memlûk tahta geçtiği bir süreç yaşanmıştır. ${ }^{16}$

Kutuz, sultan olur olmaz derhal Bedreddin el-Sincârî ve Kemaleddin İbnü'l-Adîm ile birlikte el-Melikü'n-Nâsır'a mektup gönderip Moğollara karşı kendisine yardım edebileceğini teklifinde bulunmuştur. Bunun yanında şayet Mısır'a gelirse saltanat naibi olarak yanında kalacağını ve kendisini sultan ilan edeceği taahhüdünde bulunmuştur. el-Melikü'n-Nâsır, Moğolların tehdidi karşısında hiç zaman kaybetmeden müdafaa tedbirleri almaya başlamıştır. İslam kaynakları, kendisinin Halep ve Dımaşk’tan bir hayli kalabalık bir ordu topladığını kaydederler. Bunun yanında aynı kaynaklar da el-Melikü'n-Nâsır'ın, Moğollar gibi çetin bir düşmanın önünde duracak basireti gösteremediği gibi Moğolların bölgeye vasıl olmalarıyla tüm hazırlıkları bir kenara bırakıp onlara karşı koyacak herhangi bir girişimde bulunmadığını bildirirler. Moğollar ise başında bizzat Hülegü olduğu halde Fırat nehrini geçerek Dicle Nehri üzerinden Amid önlerine gelmişlerdir (Zilhicce 657/Aralık 1259). İlhanlı hükümdarı, Amid'e vasıl olduğunda o sıralar Anadolu Selçuklu tahtını müşterek idare eden Rükneddin Kılıç Arslan ile ağabeyi İzzeddin Keykavus'a ordusuna katılmaları hususunda haber göndermişti. Hülegü kısa süre içinde Amid'i kuşatmışsa da burada oyalanmanın faydasız olacağını düşünmüş olacak ki şehir önünde bir miktar askeri birlik bırakıp el-Melikü’nNâsır'a ait Ruha ve Harran üzerine yürümüşsür. Kısa süre sonra da Harran sert bir kuşatma altına alınmıştır. ${ }^{17}$

Durumdan haberdar olan el-Melikü'n-Nâsır ise sıradakinin Suriye bölgesi olacağını düşünmüş olmalı ki paniğe kapıldığı görülmektedir. Nitekim hemen Moğollara karşı ne tür strateji uygulanacağını istişare etmek için bir meclis toplamıştır. Burada büyük komutanlardan Necmeddin Emir Hacib ve Zeyneddin el-Hafızî, Moğollara karşı direnmenin mantıksızca olacağını, boyun eğmek gerektiğini bildirmişlerdir. Filhakika bu öneri zaten panik halinde olan el-Melikü’n-Nâsır'ın gözünü daha da korkutmaktan başka bir işe yaramamıştır. Bunun yanında o sıralar mecliste hazır

15 Celâleddin Harzemşah’ın yeğeni olup 1260 yılında Memlûk sultanlığı yapmasının yanında aşağıda da anlatılacağı gibi Ayn-1 Calut savaşında Moğolları kesin bir yenilgiye uğratmıştır. Hayatı ve siyasi icraatları hakkında umumi bir mülahaza için bkz. Safedî, XXIV, s.251-254; Baybars el-Mansûrî, Tuhfe, s.40-45; İbnü'd-Devâdârî, VIII, s. 39-66; İbnü'l-Kesir, XIII, s.395-399; Makrîzî, I, s.417-438; a.mlf, el-Hitat, II, s.238; el-Aynî, I, s. 254-260; Ekrem Hasan Ulebî, et-Metikü'l-Muzaffer Kutuz, DimaşkBeyrut 1987, ilgili yerler ; Bessâm el-Aselî., et-Muzaf-fer Kutuz ve Ma'reketü 'Ayni Câlût, Beyrut 1992, ilgili yerler; Mahmud Şelbî, Hayatu'l-Melikü'l-Muzaffer Kutuz, Beyrut 1992, ilgili yerler; Şehabeddin Tekindağ, “Kutuz”, IA, VI, s.1057-1060; D. P. Little, “Kutuz”, EI², V, s.571-572.

16 İbnü'l-Amîd, s.48; Baybars el-Mansûrî, Zübde, s.36; a.mlf, Tuhfe, s.42; İbnü'l-Devadarî, VIII, s.39; İbnü'l-Kesir, XIII, s.382-383; Makrizî, I, s.417; el-Aynî, I, s.220.

17 Cûzcânî, s.445; İbni Bîbî, II, s.153-155; Ebu'l-Farac, II, s. 573; İbnü'l-Furât, s.57; İbn Dokmak, s.255; İbn Haldûn, V,s.435. 
bulunan Baybars ${ }^{18}$ ve Kalavun ${ }^{19}$ gibi büyük emirler, Moğollara mukavemet edebilecek ellerinde yeterli kuvvet olduğunu bildirerek düşmana karşı birlikte hareket edilmesini istediler. Lakin bu istek korku içinde olan Sultan ve birçok emir tarafından reddedilmiştir. Nitekim el-Melikü’nNâsır birçok hükümdarlık meziyetinden yoksun birisiydi. Kaynaklar onun savaş hazırlığı yapacak yerde, zevk ve sefa içinde günler geçirdiği kaydederler. İbn Abdüzzahir'in bildirdiğine göre elMelikü'n-Nâsır'ın umursuz tavırları Dımaşk sarayında bulunan Baybars başta olmak üzere birçok önemli emirin kendisinden uzaklaşmasına veya kendisine karşı cephe almasına neden olmuştur ${ }^{20}$. Bunun yanında işin böyle yürümeyeceğini bilen bu emirler, Sultan'1 tevkif edip ortadan kaldırmayı düşünmüşlerdir. Bu nedenle el-Melikü’n-Nâsır, dinlenmek için gittiği Dımaşk dışında bulunan ve kardeşi el-Melikü'z-Zahir'e ait olan bir bostanda iken bu emirler kendisine suikast düzenlemek için harekete geçmişlerdir. Fakat el-Melikü'n-Nâsır, kardeşi el-Melikü'z-Zahir'in erken uyarısı üzerine bostandan kaçarak canını kurtarmaya muvaffak olmuştur. Hemen can havliyle Dımaşk Kalesi'ne kaçmış, burada da şehir naibi Cemaleddin b. Yağmûr'un tavsiyesi üzerine şehir dışına çıkarak Berze'ye ${ }^{21}$ gitmiştir. ${ }^{22}$

El-Melikü'n-Nâsır'ın umursamaz tavrı yüzünden Sultan'a suikast düzenlemeyi düşünen Baybars ve arkadaşlarının bu girişiminin başarısızlıkla sonuçlanması üzerine, can güvenliğinin tehlikede olduğunu düşünerek Nablus'a gitmişlerdir. Baybars burada bulunmanın mantıksız olacağını düşünerek el-Melikü'n-Nâsır'ı terk eden birçok askerleri de yanına alıp Gazze'ye ${ }^{23}$ doğru hareket etmiştir. Burada Mısır Sultanı Kutuz'a Alâeddin Taybars el-Vezirî ile haber gönderip arkadaşlarıyla birlikte hizmetine girmek istediklerini bildirmişlerdir. Sultan Kutuz, Baybars gibi

18 1260-1277 yılları arasında Memlûk sultanlığı yapmıştır. Baybars'ın doğum tarihi tam kesin olmamakla beraber 1223 tarihinde Hazar denizinin kuzeyindeki Ural Nehri yakınlarında yer alan Atırav şehrinde dünyaya geldiği kuvvetle muhtemeldir. Kıpçak Türklerinden Borlı boyundandır (İbn Abdüzzahir, s.46). Yukarıda da ifade ettiğimiz gibi 1241 yılında Moğolların Kafkaslarda yaptığı bir sefer sırasında esir düşmüştür. Esir olarak önce Sivas, Halep ve Dımaşk'a götürüldü ve burada bir kuyumcuya satıldı. Daha sonra Hama'da mahpus bulunan Emîr Alâeddin Aytekin el-Bundukdârî tarafından satın alındı ve kendisi ile birlikte Kahire'ye gitti. Mısır'da el-Melikü's-Salih'in oluşturduğu Bahriyye Memlüklerine katıldı. Kısa bir süre içinde yükseldi ve Bahriyye Memlükleri’ninin en önemli komutanlarından biri haline geldi (İbn Şeddad, Tarihü Melikü'z-Zahir, II, s.290; Yunînî, III, s.239-240; İbnü’d-Devâdârî, VIII, s.61; Makrizî, I, s. 637; el-Aynî, I, s. 175; Safedî, X, s.239). Bunun yanında hayatı hakkında daha fazla bilgi için bkz. Şeşen, Sultan Baybars, ilgili yerler; Saîd Abdülfettah Âşûr, ez-Zâhir Baybârs, Kahire 1963, ilgili yerler; Abdulaziz Khowaiter, Baibars The First: His Endeauours and Achieoements, London 1978, ilgili yerler; Mahmud Şelbî, Hayatu'l-Melikü'z-Zahir Baybars, Beyrut 1992, ilgili yerler; M. Fuad Köprülü, "Baybars I", IA , II, s.357-363; G. Wiet, "Baybars I", EI 2 I, s.1124-1126; Kazım Yaşar Kopraman, "Baybars I”, DIA, V, s.221-223.

19 Söz konusu emir 1279-1281 yılları arasında Memlûk sultanlığı yapmıștır. Nitekim hayatı ve icraatları hakkında bkz. Baybars el-Mansûrî, Tuhfe, s. 89-126; İbnü'd-Devâdârî, VIII, s. 231-303; Makrîzî, I, s. 663-756; a.mlf, el-Hitat, s.238; el-Aynî, II, s. 225-391; İbnü’l-İyâs, I, s. s. 346-364; Ali Aktan, "Bahri Memlûklerden Sultan Kalavun ve Hanedanı", Belleten, LIX, S.226, Ankara 2003,s.605-620.

20 İbn Abdüzzahir s.62.

21 Birze-Berze “بزّز”, Dımaşk yakınlarda küçük bir yerleşim yeridir. Bkz. İbn Hurdazbih, s.119-121, 213, 246; Herevî, s.20-21; Yakut el-Hamavî, I, s.382-383

22 İbn Abdüzzahir, s.61; İbnü’l-Furât, s.56; İbn Dokmak, s.256; İbnü’l-Kesir, XIII, s. 248; el-Aynî, I, s.219; İbnü'l-Tagrîbirdî, VII, s.72-74.

23 Gazze “¿jö”,Güneybatı Filistin’de, bugün Gazze şeridi denilen bölgenin merkezidir. Antik çağlardan itibaren varlığını devam ettirmektedir. Bkz. Makdisî, s. 174; İbn Havkal, s. 172; Yakut el-Hamavî, IV, s.202-203; Zekeriyâ Kâzvinî, s.227-232; M. A. Meyer, History of the City of Gaza, New York 1907, ilgili yerler; Fr. Buhl, “Gazze”, IA, IV, s.760-761; D. Sourdel, “Ghazza”, EI², II, 1056-1057. 
bir komutanın isteğini derhal kabul etmiş ve kendisine herhangi bir şey yapılmayacağı konusunda söz verip bu davetini memnuniyetle kabul ettiği hususunda haber vermiştir. Baybars ve arkadaşları aldıkları bu söz mucibince Mısır'a doğru harekete geçmişlerdir. Tarihler 8 Mart 1260'1 gösterdiğinde ise Mısır'a varmışlardır. Ardından Sultan Kutuz tarafından birçok ikrama nail olmuşlardır. Ayrıca Baybars vezaret sarayında ağırlanarak kendisine de Kalyub ikta’ olarak verilmiştir. Burada emirler Sultan Kutuz'un emrinde Moğollara karşı savaşılacağı hususunda anlaşmışlardır. ${ }^{24}$

\section{Halep ve Dımaşk'ın Zaptı}

Bunlar olup biterken Hülegü, 8 Aralık 1259 tarihinde Harran önlerine gelerek şehri sert bir kuşatmadan sonra cebren ele geçirmiştir. Daha sonra Moğol ordusu Bire üzerine yürümüş, burası da yine aynı suretle kanlı bir şekilde Moğolların eline düşmekten kurtulamamıştır. Hülegü, o sıralar Bire'de mahpus bulunan el-Melikü'n-Nâasır'ın kardeşi el-Melikü's-Said'i serbest bırakmış ve daha önce elinde tuttuğu halde ağabeyi el-Melikü'n-Nâsır'ın elinden aldığı Subeybe ve Banyâs'1 kendisine tekrar geri vermiştir. Muharrem/Aralık aylarının sonlarına doğru Hülegü, Fırat Nehri'ni geçip Halep istikametinde yoluna devam etmiştir. Şehir yakınlarına geldiğinde bir ulak gönderip kalenin teslimi karşılığında şehre herhangi bir kötülükte bulunmayacaklarını, herkesin can, mal ve namuslarına bir şey yapılmayacağı hususunda bir elçiyle haber göndermiştir. Bunun yanında tek niyetinin şehre bir naibi atayıp yoluna devam etmek olduğu ve el-Melikü’n-Nâsır ile savaşmaya geldiğini, Halep halkı ile bir husumetlerinin olmadığını söylemiştir ${ }^{25}$

Halep Kalesi naibi el-Melikü'l-Muazzam Turanşâh, bu isteğe razı göstermediği gibi Hülegü'nün bu isteğini sert bir şekilde reddetmiş ve şehirden uzaklaşmak isteyenlere de müsaade etmemiştir. Hülegü ise talebinin reddedilmesi üzerine şehri muhasara altına almış ve kale etrafında hendek ve lağımlar açtırmıştır (18 Ocak 1260). Ayrıca hendeklerin yanlarına kalın duvarlar inşa ettirmiştir. Kısa bir süre içinde başlayan muhasara neticesinde şehir, etrafı dört bir yanda kurulan mancınıkların sert bombardımanına maruz bırakılmıştır. Moğollar, kale muhafızlarının tüm ileri harekâtlarını kanlı bir şekilde geri püskürtmüşlerdir. Neticede de Moğol birliklerinin gayreti netice vermiş ve bir hafta sonra şehrin surları işgal edilmiştir (25 Ocak 1260). ${ }^{26}$ Surun ele geçirilmesinden sonra Moğol askerleri peyder pey şehrin içine akmışlar ve halkın çoğu boğazlandığı gibi şehir içinde bulunan malların çoğu yağmalanmıştır. Hülegü, şehrin tahribi, yakma ve kıtallerden sonra 14 Safer/30 Ocak'ta bu hareketlere son verilmesi için askerlerine emir vermiştir. Nihayetinde hayat normale dönerken kale içine saklanan Turanşah ve el-Melikü'n-Nâsır'ın çocukları, cariyeleri ile birlikte sultana ait birçok mal ganimet olarak ele geçirilmiştir. Hülegü, ihtiyar olması nedeniyle Turanşâh'ın canını affetmişse de kendisi birkaç gün sonra hastalanarak vefat etmiştir. Burada İmameddin el-Kazvinî naip olarak tayin edildi ve çevrede yer alan birçok kaleye naipler atanmıştır. Uzun bir süredir Eyyûbîlerin elinde kalan bu müstahkem şehir, böylece Moğolların kontrolüne

24 İbn Abdüzzahir, s.61-62; İbnü'l-Cezerî, s.255-256; İbnü'l-Furât, s.57; İbn Dokmak, s.257; Makrizî, I, s.422; el-Aynî, I, s.219; İbnü’l-Tagrîbirdî, VII, s.73-74; Yuvalı, age, s.89-91.

25 İbnü'l-Amîd, s.53-54; İbn Şeddad, el-Alaku'l-Hatıra, III/II, s.561; Ebu'l-Fedâil, I, s. 71; Yunînî, I, s.375377; Ebu'l-Fida, III, s.199; Nuveyrî, XXVII, s.384; Reşidü’d-dîn/Neşet, I, s.305-308; İbnü’l-Kesir, XIII, s.386; İbn Haldûn, V,s.435; Makrizî, I, s.420; İbnü’l-Tagrîbirdî, VII, s.74; İbn Sibat, I, 371; el-Diyarbekri, II, s.322.

26 İbnü'l-Amîd, s.54; Ebu'l-Fedâil, I, s.71; İbn Şeddad, el-Alaku'l-Hatıra, III/II, s.561; Baybars el-Mansûrî, Zübde, s.48-49; Ebu Şame, s.203; Ebu'l-Fida, III, s.202; İbn Dokmak, s.259; Nuveyrî, XXVII, s.387; İbnü'l-Kesir, XIII, s.386; Yafi'’̂, IV, s.113; İbn Haldûn, V,s.435; Makrizî, I, s. 422; el-Aynî, I, s.231; İbn Sibat, I, 372; el-Arinî, age, 48; Philip K. Hitti, Syria: A Short History, New York 1959, s.202. 
girmiş oluyordu ${ }^{27}$. Arkasından Harim şehri de sert bir muhasaradan sonra cebren ele geçirilerek şehir yerle bir edilmiştir. ${ }^{28}$

Halep'in düştüğ̈̈ haberini alan ve sıranın kendilerine geleceğinden emin olan Hama halk1, buranın sahibi el-Melikü'l-Mansur'un efendisi el-Melikü'n-Nâsır'ın yanına kaçmasını da firsat bilerek Hülegü'ye haber gönderip Moğollara itaatlerini bildirmişlerdir (15 Safer 658/31 Ocak 1260). Nitekim el-Melikü'l-Mansur efendisinin yanına iltica ederken Hama'ya Tavaşî Mürşid'i naip olarak atamıştır. Bu emir de elindeki güçlerle Moğollara karşı mukavemet gösteremeyeceğini düşünüp şehirdeki ileri gelenlerle istişare yapmış ve hâlihazırda Moğollara teslim olmanın daha mantıklı olacağına kanaat getirmişlerdi. Hülegü, Hama'nın mukavemet göstermeden teslim olması üzerine bundan son derece mutlu olmuş ve şehre Hüsrevşah adında birini şahne ${ }^{29}$ olarak atayarak bir şükran göstergesi olarak halka dokunmamıştır. Kaynaklar buna mukabil şehirde yer alan kütüphaneye el konulduğunu yazarlar. ${ }^{30}$

Hülegü, Hama'da iken Suriye bölgesinin merkezi kabul edilen Dımaşk’a elçi gönderip teslim olmasını istemişti. Dımaşk’ta bulunan Sultan el-Melikü’n-Nâsır, Halep'in Moğolların eline zor düşeceğini düşünüyordu. Fakat Hama'nın koşulsuz teslim olmasını öğrenince yanına buranın eski sahibi el-Melikü'l-Mansûr'u da alarak Dımaşk'tan Gazze'ye doğru hareket etmiştir. Melikü’nNâsır Nablus'a vardığında buraya küçük bir birlik bırakıp başına da Mücireddin b.Ebi Zekerî ile Ali b.Şücâ'yı tayin etmiştir. Yoluna devam eden Sultan, mevsimin kış olması nedeniyle kendisi ile birlikte yola çıkan kafilesinin bir kısmını yolda kaybetmiştir. Sultan ve kafilesi Gazze'ye vasıl olduklarında Moğol takibinden korktukları için olacak ki burada fazla durmadan yollarına devam etmişlerdir. Sultan, el-Ariş'e ${ }^{31}$ vardığında yanına sadece küçük asker birliği olduğu halde Hımıs sahibinin oğulları el-Melükü’Salih ile el-Melikü'z-Zahir ve Şehabeddin Keymarî’yi bırakarak kafilesine de Misır'a gitmelerini istemiştir. Kendisi de Sina Çölü üzerinden Şevabek’e, oradan da Kerek'e $^{32}$ gitmiştir. Burada çok iyi bir şekilde ağırlanmışsa da Moğollardan korktuğu için şehirde fazla duramamış ve Berketü'z-Ziza' da gizlenmiştir. ${ }^{33}$

El-Melikü'n-Nâsır'ın teberdarı Hüseyin el-Kürdî, gizlice Ketboğa Noyan'ın yanına gelerek, şayet kendisine Hıdru'l-Havlan'1 verirse el-Melikü'n-Nâsır'ı gizlendiği yeri söyleyebileceği teklifinde bulunmuştur. Ketboğa bunu kabul edip yanına bir miktar asker alarak el-Melikü'nNâsır'ın gizlendiği yere baskın düzenlemiştir. Bu baskın sonucu birçok Eyyûbî meliki ile birlikte

27 Baybars el-Mansûrî, Zübde, s.49; İbnü'l-Devadarî, VIII, s.46; İbn Dokmak, s. 259; İbnü'l-Kesir, XIII, s.386; el-Aynî, Siret el-Melikü'l-Mü'eyyed, s.23.

28 Baybars el-Mansûrî, Zübde, s.49-50; Ebu'l-Fida, III, s.202; İbnü'l-Devadarî, VIII, s.46; Nuveyrî, XXVII, s.387; İbnü'l-Kesir, XIII, s.386.

29 Bir şehir veya bölgeye atanan ve genellikle asayiş işlerine bakan askeri valilere verilen isimdir. Bkz. Erdoğan Merçil, "Şahne”, DIA, XXXVIII, s.292-293.

30 İbnü'l-Amîd, s.50; Ebu'l-Fedâil, I, s. 71; Ebu'l-Fida, III, s.213; Nuveyrî, XXVII, s.388.

31 el-Ariş “" "شيرحل, Kuzey Mısır'ın idari kısımlarından birisidir. Bkz. Yakut el-Hamavî, IV, s.261-266; İbnü'l-Abdulhak, II, s.945; Zekeriyâ Kâzvinî, s.221; Makrizî, et-Hıtât, I, s.210-211; F. Buhli, "el-'Ariş”, IA , IV, s. 221.

32 Kerek "كرك", bu gün Ürdün sınırları içersinde yer alan şehir, Lut gölünün $15 \mathrm{~km}$. kadar doğusunda, denizden 1000 m. yükseklikteki Kerek platosunun çok sarp bir kesiminde kurulmuştur. Bkz. Herevî", s.19-20 Fr. Buhl, "Kerek”, IA, VI, 583-584; D. Sourdel, "al-Karak”, $E I^{2}$, IV, s. 609.

33 İbnü’l-Amîd, s.52; Ebu’l-Şame, s.203; İbn Dokmak, s.259; Yafi'î, IV, s.113; Makrizî, I, s.424; el-Aynî, I, s.232; İbnü'l-Tagrîbirdî, VII, s.70-71. 
el-Melikü'n-Nâsır'ı ele geçirmiştir. Bu sırada Aclun Kalesi de Moğollar tarafından muhasara altına alınmıştı ve kale tüm saldırılara rağmen direnmekteydi. Ketboğa kaleyi müdafaa eden güçlere gözdağı vermek amacıyla yanında el-Melikü'n-Nâsır olduğu halde kale önüne gelerek derhal kalenin teslim olmasını istemiştir. Çaresiz kalan el-Melikü'n-Nâsır kaleye haber göndermek zorunda kalmış ve kaleyi müdafaa eden askerler Sultan'ın telkini üzerine kaleyi teslim etmiştir. Bu gelişmenin akabinde Moğollar kuvvetleri tarafından Busra ve Subeyda kaleleri cebren de olsa ele geçirilmiştir. ${ }^{34}$ Dımaşk halkı ise sultanlarının kendilerini bırakıp kaçmaları üzerine Moğollara teslim olmanın daha faydalı olacağını düşünerek o sıralar Haras’ta bulunan Hülegü’ye elçi göndermişlerdir. Elçiler Moğol hükümdarının huzuruna çıkarak, Dımaşk’a elçi sıfatı ile bir birlik göndermelerini ve şehri Moğollara teslim etmek istedikleri bildirmişlerdir. Bunun üzerine Hülegü, naiplerinden Balaban el-Sırri ve Kadı Alâeddin el-Acemi’yi şehri teslim almaları için Dımaşk'a göndermiştir. Naipler 19 Safer/4 Şubat’a Dımaşk’a varıp şehri teslim almışlardır. Hülegü, burada daha önce şehirde Başkadılık görevini yapan Muhyiddin b. el-Zeki'yi naip olarak atamıştır. ${ }^{35}$

Dımaşk gibi Suriye bölgesinin kilit şehri hüviyetindeki bir şehrin mukavemet göstermeden teslim olması Moğollar için büyük bir başarı olmuştu. Fakat Hülegü, şehri teslim aldığı sıralarda Moğolların ana merkezi Karakurum'dan hiç beklenmedik bir haber almıştır. Bu habere göre büyük hükümdar Mönge Han ölmüş ve bu boşluktan faydalanan Arıkboğa kendisini "Büyük Kaan" olarak ilan etmişti. O sıralar Çin'de seferde iken haberi alan Kubilay derhal Karakurum'a gelmiş ve Arıkboğa’yı bertaraf edip kendisi tahta geçmişti. Moğol tahtında bunlar olup biterken Hülegü'nün bundan haberi olmuş ve derhal Suriye bölgesini terk ederek Suruc ve Ahlat üzerinden İran’a dönmüştür. ${ }^{36}$ Kaynaklar, Hülegü’nün Suriye'de Ketboğa Noyan'ın emrinde sayısı 12.000 ile15.000 arasında olan bir birlik bıraktığını ve Mardin'in kuşatılması hususunda da komutanına emir verdiğini kaydederler ${ }^{37}$.

Ketboğa Noyan ise Mardin'i sert kuşatma altına almış ve Mardin hâkiminin ölmesi ile oğlu Kara Aslan tarafından sulh yolu ile Moğollara teslim olmuştur. Bundan sonra Ketboğa Noyan, ordusunun başında Dımaşk'a geri dönmüştür. Şehir halkı olası bir yağma ihtimalinden dolayı düşman askerlerini şehrin içine almamışlardır. Bunun üzerine Moğollar yollarına devam edip Harran ve Filistin'e doğru hareket etmişlerdir. Nablus ${ }^{38}$ önlerine geldikten kısa bir süre sonra şehri muhasara altına almışlardır. Yukarıda da belirtildiği gibi Melikü’n-Nâsır buraya Mücireddin b.Ebi Zekerî’yi atamıştı. Mücireddin b.Ebi Zekerî düşmana karşı koymaya çalışmış ve düşman askerlerine de bir hayli zayiat verdirmesine rağmen bunlara fazla direnememiş ve Moğollarla savaşırken bir çarpışma sırasında öldürülmüş, müdafaa ettiği şehir ise kısa bir süre sonra Moğolların eline geçmiştir. ${ }^{39}$

34 İbnü'l-Amîd, s.53; Ebu'l-Şame, s.203-204; Yunînî, I, s.357-358İbn Dokmak, s.260; Nuveyrî, XXVII, s.389; İbnü'l-Ahmed el-Askalânî, s.371; Zehebî, Tarihü'l-İslam, XLVIII, s.63; Makrizî, I, s.424.

35 Yunînî, I, s.351-352; Baybars el-Mansûrî, Zübde, s.50; Ebu Şame, s.204; İbnü’l-Cezerî, s.257; İbnü’lFurât, s.58; İbn Sibat, I, s.388-389; İbnü'l-Devadarî, VIII, s.46-47;İbnü'l-Kesir, XIII, s.387-388; İbn Haldûn, V,s.436; Makrizî, I, s.426; el-Aynî, I, s.240; a.mlf, Siret el-Melikü'l-Mü'eyyed, s.23; el-Arinî, age, s.48; Hitti, age, s.202.

36 Ebu Şame, s.205; Nuveyrî, XXVII, s.390.

37 Baybars el-Mansuri, Tuhfe, s. 84; Ebu'l-Farac, II, s.575; Makrizî, I, s.427; Yuvalı, age, s.90-91.

38 Nablus “سلبان", bugün Filistin toprakları içerisnde yer alan ve Ortaçağ boyunca önemli mevkide bulunan bir şehirdir. Bkz. Yakut el-Hamavi, IV, s.248-249.

39 İbnü'l-Amîd, s.53; Ebu'l-Şame, s.205; Baybars Mansurî, Tuhfe, s. 84; Ebu'l-Farac, II, s.575; İbn Dokmak, s.260; Nuveyrî, XXVII, s.390; İbn Haldûn, V,s.435. 


\section{Ayn-ı Câlût Savaşı}

Moğollar, girdikleri Suriye bölgesinde etrafı tarumar edip yollarına devam etmişlerdir. Nitekim Havran ${ }^{40}$, Salt, Birketü’z-Ziza, Beytü'l-Cibril, Kudüs ${ }^{41}$ ve Gazze peş peşe ele geçirilmiştir. $\mathrm{Bu}$ şehirlerde büyük bir katliam gerçekleştirdikten sonra birçok mevki talan etmişlerdir. Önlerine gelen insanların çoğu doğranmış, sağ kalanlar da esir alınmıştır. Kaynaklar, bunlara ek olarak Gazze'ye kadar uzanan bu seferden sonra Moğolların Dımaşk'a geri çekildiğini kaydederler. Burada ele geçirdikleri ganimeti ve esirleri satmışlardır. Fakat Moğollar, Dımaşk’a geldiklerinde hiç beklenmedik bir hadise yaşanmış ve burada kendilerine karşı Bedreddin Kızıl ile Cemaleddin el-Seyrafî önderliğinde bir isyan patlak vermişti. Bunun üzerine Dımaşk kalesi tekrar Moğollar tarafından muhasara altına alınmış ve kale kısa bir süre sonra mancınıkların sert bombardımanı karşısında da şehir halkı teslim olmak zorunda kalmıştır (22 Cemaziyelevvel 658/5 Mayıs 1260). Kale içine akan Moğol askerleri Bedreddin Kızıl ile Cemaleddin el-Seyrafî’yi tutuklayıp idam edilmiştir. Bunun yanında Dımaşk’taki bu isyan Moğol birliklerinin canını bir hayli sıkmış olmalı ki buna benzer bir hadisenin gerçekleşmemesi ve etrafa gözdağı vermek amacıyla yakınlarda bulunan Ba'lebek önlerine gelip kaleyi muhasara altına almışlardır. Şehir her ne kadar mukavemet göstermişse de neticede kalenin müdafileri teslim olmak zorunda kalmıştır. ${ }^{42}$

Moğolların Suriye bölgesini ele geçirmeleri üzerine, İslam dünyasının son kalesi olarak Mısır kalmıştı. Burada da devlet ümerası ve halkı, korku içinde bölgeden kaçan kişilerden Moğol vahşetini dinliyorlardı. Mısır'ın da ele geçirileceğine inanan birçok kişi Afrika'nın daha kuzey-batı kısmına kaçmayı daha uygun bulmuştu. Fakat Mısır' da Moğollara karşı yapılacakların görüşüldüğü mecliste devlet ümerası arasında ihtilaflar çıkmıştır. Nitekim bir kısım emir Moğollara karşı direnmenin fayda getirmeyeceğini dile getirirken, Baybars gibi emirlerin ise 1srarla Moğollarla savaşılması gerektiğini söylemişlerdir. Nihayetinde Baybars'ın ısrarı üzerine Sultan Kutuz, Moğollara karşı konulacağına karar vermiştir. Bu nedenle savaş giderlerinin karşılanması için Melikü'n-Nâsır'ın Mısır'a iltica etmiş olan eşinin ve Cemaleddin b. Yağmûr'un mallarına da el konulmuş ve kendileri de tevkif edilmiştir. Kısa bir süre içinde Mısır' da Moğollara karşı genel bir seferberlik ilan edilmiştir. ${ }^{43}$ Sultan Kutuz, savaş hazırlığı yaptığı sıralarda Kahire Sarayı'na gelen Moğol elçisi elinde tehditler dolu bir mektubu Memlûk hükümdarına sunmuştur. ${ }^{44} \mathrm{Bu}$ mektupta tehditlerin yanında Cengiz Han Yasası'nı kabul edip derhal Moğolların yüksek hâkimiyetini tanımaları, aksi takdire başlarına büyük bir felaketin geleceği yazılı olduğu bilinmektedir. ${ }^{45}$

40 Havrân “نارود”, Dımaşk’a bağlı bir nahiye olup müstahkem bir kalesi bulunmaktaydı. Bkz. Zekeriyâ Kâzvinî, s.185.

41 Kudüs "wد", Lut gölünün bulunduğu çukur alanın batısında, dikliklerle ayrılmış olan Yahudiye platosunun dalgalı yüzeyi üzerinde kurulmuştur. Üç ilâhî dinde de önemli yere sahip olan ve kutsal sayılan bir şehirdir. Kuruluşu antik çağlara kadar gider. Konumu hakkında bkz. Makdisî, s.159 vd; Nâsır-1 Hüsrev, s. 31-56; F. Buhl, "Kudüs”, İA, VI, s.952-964; Muammer Gül, XI.-XIII. Yüzyıllarda Kudüs, Fırat Üniversitesi Sosyal Bilimler Enstitüsü Basılmamış Doktora Tezi, Elazığ 1997, ilgili yerler.

42 Ebu Şame, s.205-206; Yunînî, I, s.351-358; Ebu'l-Fida, III, s.202-213; İbn Dokmak, s.260; İbnü’lTagrîbirdî, VII, s.70-80; İbnü’l-Kesir, XIII, s. 220-227; Makrizî, I, s.424-433.

43 Reşîdu'd-dîn/Neş'et, I, s.310; İbnü'l-Furât, s.58; Kalkaşandî, VIII, s.63-64; İbnü’l-Kesir, XIII, s.388399; Makrizî, I, s.423; Yuvalı, age, s.91.

44 Mektubun muhtevası için bkz. Makrizî, I, s.427-428; İbnü'l-Devadarî, VIII, s.47-48; İbn Dokmak', s.261-262; Kalkaşandî, VIII, s.64-65; İbnü'l-İyas, I, s.304-305.

45 Reşîdu'd-dîn/Neş’et, I, s.310; İbnü'l-Furât, s.58; İbn Dokmak, s.262; Kalkaşandî, VIII, s.63-65; Makrizî, I, s. 27-428; İbnü'l-İyas, I, s.304-305; Yuval1, age, s.91. 
Sultan Kutuz, emirlerini derhal Kala'tu'l-Cebel'e ${ }^{46}$ çağırarak, Moğolların mektubunu okuduktan sonra düşmana karşı ne yapılması gerekti konusunda istişare etti. Emirlerin bir kısmı Moğollarla savaşılması hususunda hala bir korku içindeydiler. En nihayetinde Sultan Kutuz ve Emir Baybars bütün emirleri ikna ettiler. Buna göre müşavereden Moğollara karşı savaşılacağ1 kararı çıktı ve bu münasebetle düşmana gözdağı vermek amacıyla elçilerin tümü öldürüldü. ${ }^{47}$ Moğol elçilerinin öldürülmesi karşısında düşman ordusunun harekete geçeceğini bilen Sultan, ordusu başında Kahire'de hareket emri verdi(15 Şaban 658/26 Temmuz 1260). Memlûk ordusunda Mısır askerleri, Nâsırîler, Şehrazur Kürt askerleri" ${ }^{48}$ ile birlikte el-Melükü'l-Mansur, el-Melikü'sSaid b. Bedreddin Lu'lu' gibi önemli kişiler de bulunmaktaydı. Bunların yanında Suriye bölgesinde Moğollardan kaçan birçok asker de Memlûk ordusunun bünyesine alındığı gibi ordu da iyice teçhiz edildi. ${ }^{49}$ Sultan Kutuz, Baybars'1 öncü birliklerin komutasına getirip ileri hareket emri verdi. ${ }^{50} \mathrm{Bu}$ öncü birlik süratli bir şekilde ilerlerken, Gazze'ye kadar sokulan Baydara komutasında bir Moğol müfrezesi de Memlûk ordusunun harekete geçtiğini duymuş ve derhal geri çekilerek vaziyeti Ketboğa Noyan'a haber vermiştir. Kutuz, kısa bir süre sonra ordusunun başında olduğu halde Gazze’ye girdi. Burada bir gün konakladıktan sonra Akka üzerinden hareket etti. Söz konusu yeri ellerinde tutan Haçlı birlikleri ile anlaşarak birbirlerine karşı herhangi bir düşmanca harekette bulunmayacakları hususunda güvence aldı. Bunun yanında Haçlı reisleri de Memlûk ordusuna katılmak istediklerini söyleyince, Sultan Kutuz teşekkür edip bu tekliflerini nazikçe geri çevirmiştir. ${ }^{51}$

Burada Haçliların Memlûklere destek vermeleri ise bir hayli ilginç bir hadise olarak görülmektedir. Bunda büyük bir ihtimalle Moğollar'ın Haçlıları bile tehdit edecek boyutta bölgeyi tahrip etmelerinin etkisi olmalıdır. Ayrıca Kitboğa Noyan'ın Memlûklere karşı gelecek bir saldırı ihtimaline karşı da onların en büyük düşmanı olan Haçlıları tarafına çekmeyi ihmal ederek büyük bir hatada bulunmuştu. Esasen Hülegü'nun Suriye'de bıraktığı ordu da Suriye'de ele geçirilen yerleri korumak için bırakılmıştı ve büyük bir ihtimalle Mısır'a karşı saldırı niyetinde değillerdi. Fakat Ketboğa Noyan, Kutuz'un ordusunun başında Gazze’yi geçtiğini Bika'da iken öğrendiğinde savaşı da kabul etmek zorunda kaldı. Komutanlarıyla istişare ettiğinde, Memlûklere karşı savaşılması hususunda karar kıldılar. Bunun yanında Ketboğa Noyan, böyle bir hareketi Memlûklerden beklemiyordu ve ordusu ile birlikte hazırlıksız yakalanmıştı. Nihayetinde Moğol

46 Kale hakkında bkz. Suyutî, Hüsnü'l-Muhadâra, II, s.297

47 Kalkaşandî, VIII, s.64; Makrizî, I, s.423.

48 İbnü'd-Devadarî, VIII, s.48.

49 Baybars el-Mansûrî, Zübde, s.50;a.mlf, Tuhfe, s.43; İbnü'd-Devadarî, VIII, s.48; İbnü’l-Kesir, VIII, s.227,251; Makrizî, I, s.430; el-Aynî, I, s.330; İbnü'l-İyas, I, s.304-305.

50 İbn Abdüzzahir, s.63; Reşîdu'd-dîn/Neş'et, I, s.317; İbn Dokmak, s.262; Makrizî, I, s.430-431; İbnü’lTagrîbirdî, VII, s.79-80.

51 İbn Abdüzzahir, s.63; Yunînî, I, s.365; İbnü'd-Devadarî, VIII, s.49; İbn Dokmak, s.262-263; Makrizî, I, s.429-430; el-Arinî, age, s.49; Abdullah Said el-Gamidî, Cihadü'l-Memalik Deydü'l-Moğoliye ve'lSalibiyin, Mekke 1986,s.139-141; Memlûk-Haçlı İlişkileri Hakkında bkz. Ali Aktan, "Memlûk-Haçlı Münasebetleri”, Belleten, LXIII, S.237, Ankara 1999, s.411-452; Azmî Abd Muhammed Ebu Alyân, Mesiretü'l-Cihadü'l-İslami Dadu'l-Salibîŷ̂n fi Ahdü'l-Memâlik, Erden 1994, ilgili yerler. 
komutan1, askerlerine hareket emri verdi ${ }^{52}$ ve bu münasebetle ordusu Ayn-1 Calut ${ }^{53}$ bölgesinde mevzilenerek Sultan Kutuz'un ordusunu beklediler. ${ }^{54}$ Sultan Kutuz, Atabekü'l-Asakir Aktay, elMelikü'l-Mansur ile birlikte ordunun başında ilerlerken Baybars'1 da pişdar birliğin başında ileriye gönderdi. Baybars, Beysan'a geldiğinde Moğolların Ayn-1 Calut'ta mevzilendiğini görünce duruma sultana bildirerek Moğolların pişdar birliğini de kısa çatışmalarla oyalayarak zaman kazanmaya çalıştı. Nihayetinde Moğollar, Memlûklerin mezkûr bölgeye ulaşmalarının akabinde, düşman birliklerinin karşısında mevzilenerek savaş düzeni aldılar. ${ }^{55}$

Kaynakların ifadesine göre savaş, Moğol ordusunun şiddetli bir taarruzu ile başladı. Moğollar, süratli bir şekilde Memlûklerin mevzilendiği alana doğru harekete geçtiler. Şiddetli hücum ile birlikte Memlûk ordusunun sol kanadı dağıldı. Bunun üzerine başarılı bir manevra ile Sultan Kutuz, Baybars ve Emir Aktay düşman ordusunun merkez birliğine hücumu savaşın sonucunu belirledi: Moğol ordusu büyük hezimete uğradı. Kaynakların ittifak ettikleri gibi kahramanca savaşan Ketboğa ise savaş alanında öldürüldü. Baydara komutasında küçük bir Moğol birliği ise çareyi etraftaki dağlara kaçmakta buldu. Baybars derhal bunların peşine düşerek bu birliğe de bir hayli zayiat verdirdi. Bunun yanında bizzat Ketboğa'nın oğlu ve eşinin olduğu birçok kişi de esir olarak ele geçirildi(25 Ramazan 658/3 Eylül 1260). ${ }^{56}$ Fakat bu önemli savaşın ardından Sultan Kutuz bizzat Baybars tarafindan öldürülerek yerine sultan olacaktır. ${ }^{57}$ el-Melikü'n-Nâsır ise yanlış istihbarat verdiği gerekçesiyle Moğollar tarafından feci bir şekilde katledildi. ${ }^{58}$ Savaşın ardından Moğolların İslam dünyasına doğru istila hareketi ilk kez durdurulmuş ve bu başarı ile Suriye bölgesinin çoğu Ayn-1 Calut savaşı ile birlikte Memlûklere ilhak olmuştur. Bu tarihten itibaren bölgede yoğun Moğol-Memlûk mücadelesi başlamıştır.

\section{Sonuç}

İslam tarihi kaynaklarında büyük yer edinen İlhanlıların Suriye seferi, hem İslam Coğrafyası'nda Moğollar tarafından zapt edilemeyen Suriye ve Mısır'a karşı yapılmış olması hem de Moğolların söz konusu sefer sonucunda Ayn-1 Câlût bölgesinde yenilgiye uğramalarının neticesi

52 Moğol ordusunun mevcudu hakkında elimizde yeterli bir bilgi yoktur. Nitekim kaynaklar bir birinden çok farklı sayılar verirler. Baybars el-Mansûrî Moğol ordusunun sayısını 12.000 (Tuhfe, s.63), Ebu'l-Farac 10.000 (II, s.575), Nuveyrî ise 20.000 olarak gösterir. Bunun yanında kanaatimizce bu sayısının 10.000 civarında olduğudur. Memlûk ordusunun sayısı ise bunun yaklaşık iki katı olduğu şüphe götürmez.

53 "تول اج نيء", Arapçada “Calut'un Gözü” anlamına gelen bu mevki Filistin'e bağlı Beysan ile Nablus arasında bir mevkidedir. Bkz. Yakut el-Hamavî, IV, s.117.

54 Baybars el-Mansûrî, Zübde, s.51; İbn Dokmak, s.263; Makrizî, I, s.431-433; İbnü'l-Tagrîbirdî, VII, s.80; el-Gamidî, age, s.141-144.

55 Baybars el-Mansûrî, Zübde, s.51; Makrizî, I, s.429-431.

56 İbnü'l-Amîd, s. 53-54; İbn Abdüzzahir, s.63-66; Yunînî, I, s.365-367; Ebu Şâme, s.207-209; İbnü’lFuvâtî, s.166; İbnü'l-Furât, s.58-60; Baybars el-Mansûrî, Zübde, s.50-52;a.mlf, Tuhfe, s.43-45; Ebu'lFedâil, I, s. 75; Reşîdu'd-dîn/Neş'et, I, s.313-316; Ebu'l-Fida, III, s.205; Zehebî, Tarihü'l-İslam, XLVIII, s.60-62; a.mlf, Düvelü'l-İslam, II, s.163; İbn Dokmak, s.263-266; İbnü'l-Kesir, XIII, s. 388-392; Yafi'î, IV, s.113; Nuveyrî, XXIX, s.474; İbn Sibât, I, s.391;Kalkaşandî, VIII, s.430; İbnü'l-Devadarî, VIII, s.4961; Makrizî, I, s.430-431; el-Aynî, I, s.243-244; İbnü'l-Tagrîbirdî, VII, s.77-81; İbnü’l-İyâs, I, s.306.

57 İbn Abdüzzahir, s.68; Baybars el-Mansûrî, Zübde, s.53-54; İbnü'l-Fuvatî, 257; İbnü’l-Furât, s.60-66; Ebu Şame, s.211; Yunînî, I, s.371; Ebu'l-Farac, Muhtasar, s.282; Ebu'l-Fida, III, s.207; İbnü'l-Devadarî', VIII, s.61-66; İbn Dokmak, s.67-68; Zehebî, Tarihü'l-İslam, XLVIII, s.64-65; a.mlf, Düvelü'l-İslam, II, s.163; İbnü’l-Kesir, XIII, s.392-394; Makrizî, I, s.435; el-Aynî, I, s.261-262; İbnü’l-Tagrîbirdî, VII, s.83 
olarak yenilemez sıfatını kaybetmeleri münasebetiyle İslam tarihinde mühim bir yere sahiptir. Büyük Moğol Hükümdarı Mönge Han tarafından İran ve Irak’ın ele geçirilmesi ile görevlendirilen Hülegü, 1256 yılında İsmaili Kalelerini, 1258 yılında da Bağdad'1 zapt ettikten sonra Suriye'ye girmiştir. İslam kaynaklarına göre İlhanlıların bu seferi bölgenin o döneme kadar yaşadığı en büyük istila hareketidir. Sefer sonucunda Halep ve Dımaşk gibi sadece Suriye bölgesinin değil, devrin İslam dünyasının da en önemli şehirlerinin Moğolların eline geçmesi üzerine Müslüman halkı dehşete düşürmüştür. Bölgedeki Eyyûbî hükümdarlarının savaşmak yerine kaçıp gitmeleri de bundaki esas amil olmuştur. Irak’tan Filistin sahillerine kadar nerdeyse tüm İslam şehirleri Moğolların kontrolüne girerken, 1260 yılında yönlerini İslam'ın son kalesi sayılan Mısır'a çevirmişlerdir. Moğol askerleri bu sefer ile meşgul iken Büyük Moğol İmparatorluğu'nun tahtında yaşanan iktidar mücadelesi sebebiyle Hülegü doğuya dönmek zorunda kalmıştır. Bu sebeple söz konusu askeri harekâtlara ara verilmiş, fakat Memlûkların karşı hamlesi üzerine iki taraf arasında Ayn-1 Calut'ta büyük bir savaş yaşanmıştır. Neticede Moğollar tarihte ilk defa bozguna uğratılmıştır. Moğolların Suriye bölgesinde ele geçirdikleri birçok mevki ise tekrar Müslümanlara terk edilmek zorunda kalınmıştır. Sonuçları itibari ile İlhanlıların batıdaki son büyük fetih dalgası iken ve Halep ile Dımaşk gibi çok önemli şehirleri ele geçirmelerine rağmen Ayn-1 Calut'ta yaşanan muvaffakiyetsizlik sebebiyle Suriye' deki ele geçirdikleri tüm yerleri kaybetmişlerdir. Moğolların bu yenilgisi sadece bölgesel bir hadise olarak kalmamış, aksine İslam'ın hem Moğollara hem de uzun bir süredir mücadele ettikleri Haçlılara karşı büyük bir moral kaynağına dönüşerek bir anda Memlûklerin önderliğinde başlatılan bir cihad fikri ile devam etmiştir. Bu sebeple Hülegü'nün başlattığı söz konusu seferinin büyük bir başarısızlık ile bitmesiyle Moğollar, Fırat'ın doğusuna atıldıkları gibi Abâkâ ve Gazan devrinde devam edecek saldırılar karşısında Memlûkler de başarılı bir şekilde mücadele edeceklerdir.

\section{Kaynakça}

Aynî, İkdü’l-Cümân fî Târîhi Ehli’z-Zamân, (Neşr. Muhammed M. Emin), I, Kahire 1987.

Barthold, V.V., "Hülagu”, İA, V/1, s. 581-582.

Baybars el-Mansûrî, Zübdet el-Fikre fi Tarih el-Hicre, (Tah. D. S. Richards), Beyrut 1998.

Dımaşkî, Cosmographie, (Neşr. M.A. F.Mehren), Saint-Petersbourg 1866.

Ebu Şame, Zeyl er-Ravzateyn, (Neşr. Abdülaziz el-Attar el-Hüseyni), Beyrut 1974.

Ebu'l-Fidâ, Tarih Ebu'l Fidâ, Muhtasar fi Ahbaru'l-Beşer, (Tah. Muhammed Azb vd),III, Bağdad 1968.

-------, Takvimü'l-Büldân, (Neşr. M.Reinaud), Paris 1840.

el-İdrisî, Nüzhetü'l-Müştâk, II, Beyrut 1989.

Fehervâri, G., "Harran”, EI², III, s.233-237.

Fehmî, Abdü's-Selam Abdü'l-Aziz, Tarih-i Devleti Moğoliye fi İran, Kahire 1981.

Grousset, Rene, Bozkır İmparatorluğu, İstanbul 1980.

Hamdullah Müstevfî, Nüzhetü'l-Kulûb, (Neşr: Le Strange), Leiden 1908.

Işıltan, Fikret, Urfa Bölgesi Tarihi, İstanbul 1960.

İbn Abdüzzahir, er-Ravzü’z-zâhir fî Sîreti'l-Meliki’z-Zâhir, (Neşr. Abdülaziz el-Huveytır), 
Riyad 1976.

İbn Dokmak, Nüzhetü'l-Enam fi Tarihü'l-İslam, (Tah.Samir Tabbare), Beyrut 1999.

İbn Haldûn, Tarih İbn Haldun, V, Beyrut 2006.

İbn Havkal, Sûretu'l-Arz, (Neşr.M.J. de Goeje), Leyden 1874.

İbn Hurdazbih, Kitabu'l-Mesâlik ve'l-Memâlik,(Neşr.M.J. de Goeje), Leyden 1890.

İbn Sibât, Sidk el-Ahbar: Tarih-i İbn Esbat, (Tah. Abdülselam Tedmurî),I, Trablus 1993.

İbn Şeddad, el-Alâku'l-Hatira fi Zikri Ümerai Şam ve'l-Cezire, (Neşr. Y. Abbare), III/I, Dımaşk 1978.

, Tarih’ul-Melik’z-Zahir,( Neşr. Ahmed Hatit), II, Beyrut 1983.

İbn Tagrîbirdî, en-Nucûm ez-Zâhire fi Mulûk Misr ve el-Kahire, (Tah.İ.Ali Tarhan-M. Mustafa Ziyade), VII, Kahire 1963.

İbn Vasıl, Müferricu'ul-Kurub Ahbar-1 Beni Eyyub, (Tah. Abdülselam Tedmurî), VI, Beyrut 2004.

İbnü'l-Amîd, Ahbar Eyyûbî yin, (Neşr. Claude Cahen ), BEO’dan tıpkıbasım, Port Said tz.

İbnü’l-Cezerî, Havâdisü’z-zaman ve enbâüh ve vefeyâtü'l-ekâbir ve'l-a ‘yân emlin ebnâih/ Muhtar Tarih-i İbnü'l-Cezer,î (Tah. Hızır Abbas Muhammed Halife el-Mendşedavî ), Beyrut 1988.

İbnü'l-Devadarî, Kenzü'd-Dürer ve Câmiu'l-Gurer: ed-Dürrü'l-Fâhir fî̀ Sîreti'l-Meliki'nNâsır, (Neşr. Hans Robert Roemer),VIII, Kahire 1960.

İbnü'l-Fuvâtî, Havadisü'l-Camia ve't-Tecaribü'n-Nafi'atü'l-Meti's-Sabi'a, Beyrut 1407.

İbnü'l-İyâs, Bedâyiü’z- Zuhûr fi Vekâyi’ i’d-Duhûr, (Tah. Muhammed Mustafa), I, Kahire 1982.

İbnü'l-Kesîr, El-Bidaye ve'n-Nihaye, (Çev. Mehmet Keskin), XIII, İstanbul 1995.

İbnü'l-Verdî, Tarih İbn Verdî, Tetimmet'ül Muhtasar fi Ahbaru'l-Beşer, II, Beyrut 1996.

İkbâl, Abbas, Tarih-i Moğul, I-II, Tahran 1926.

İstahrî, Kitabu'l-Mesalik ve'l-Memalik, (Neşr. M.J. de Goeje), Leyden 1927.

Kafalı, Mustafa, Altın Orda Hanlığının Kuruluş ve Yükseliş Devirleri, İstanbul 1976.

Kalkaşandî, Subh el-‘Aşâ fî Sinâ’at el-İnşâ, I-XIV, Kahire 1913-1920.

Kudame bin Cafer,Kitabu'l-Harac, (Neşr. M.J. de Goeje), Leyden 1890.

Lockhart. L, “Alamut”, EI², I, 352.

D’Ohsson, M. Le Baron, Histoire Des Mongols, II, Amsterdam 1852.

Makdisî, Ahsenü’t-Takasim fi Marifetü'l-Ekalim, (Neşr. M.J. de Goeje), Leyden 1877.

Makrizî, Kitabu's-Sulûk li Marifet’ud-Duvel Mulûk, (Neşr. Mustafa Ziyade), I, Kahire 1956.

Merçil, Erdoğan, "Şahne”, DİA, XXXVIII, s.292-293.

Mesudî, Kitabü'l-Teşbih ve'l-Eşraf, (Neşr. M.J. de Goeje), Leyden 1894. 
Nuveyrî, Nihâyetü'l-Ereb fî̀ Fünûni'l-Edeb , (Neşr. M. Mustafa Ziyâde), XXVII, Kahire 1990.

Özdemir, Mehmet, Moğol İstilası Cengiz ve Hülagü Dönemleri, İstanbul 2011

Sıbt İbnü'l-Cevzî, Mir'âtü'z-Zamân fî̀ Târîhi'l-a'yân, (Haz. James Richard Jewett), VIII, Chicago 1907.

Spuler, Bertold, "İlkhâns”, EI², s.1121-1123.

,"İlhanlilar", İA, V/2, s.967-972.

, İran Moğolları (Çev. Cemal Köprülü), Ankara 1987.

Suyutî, Târih-i Hülafâ, Beyrut 2003.

Sümer, Faruk, “Ağaçeriler”, Belleten, XXVI /103 (1963), s.521-528.

, Oğuzlar, İstanbul 1999.

Şeşen, Ramazan, "Harran ve Türk-İslâm Tarihindeki Yeri”, Şanlıurfa ve GAP Sempozyumu Bildirileri, İstanbul 1988, s. 159-167.

, Harran Tarihi, Ankara 1993

Togan, Zeki Velidi, “Alamut”, İA, I, s.289.

Turan, Osman, Doğu Anadolu Türk Devletleri Tarihi, İstanbul 2004

Uzunçarşılı, İsmail Hakkı, Osmanlı Devleti Teşkilatına Medhal, Ankara 1988.

Vladimirtsov, Y., Moğolların İçtimai Teşkilâtı, (Çev. Abdülkadir İnan), Ankara 1944.

Weir, T. H., "Harran", İA, V/I, s. 299-300.

Yafi' '̂̀, Miratü'l-Cinan ve İbretü'l Yakzan Ma'rife ma Yu'teber min Havadis ez-Zaman,(Neşr. Halil el-Mansur), IV,Beyrut 1997.

Yakut el-Hamavî, Mu'cemü'l-Büldân, I-V, Beyrut 1977.

Yunînî, Zeyl Miratu’z-Zaman, I-III, Haydarabad 1955.

Yuval1, Abdulkadir, "Hülâgû", DİA, XVIII, s.474-475. -, İlhanlılar Tarihi I Kuruluş Devri, Kayseri 1994.

Zehebi, Düvelü'l-İslam, (Neşr. Hasan İsmail Merket-Mahmud el-Ernaut), II, Beyrut 1999. , Târîhu'l-İslâm ve Vefeyâtü'l-Meşâhîr ve'l-A'lâm, (Tah. Ömer Abdüsselam Tedmuri), XLVIII, Beyrut 1997.

Zekeriyâ Kâzvinî, Asaru'l-Bilad ve Ahbaru'l-İbad, Beyrut 1960. 